\section{Viola Candice Milton}

Viola Candice Milton is a lecturer in the Department of Afrikaans at the University of Pretoria. She is currently completing a Ph.D. dissertation on representations of HIV/Aids and people living with Aids in Southern Africa at Indiana

University, Bloomington (USA).

\section{Time's Picturing of HIV/Aids:}

International perceptions of disease in Africa

\title{
Time's Picturing of HIV/Aids: International perceptions of disease in Africa
}

This article is an exploration of the February 12,2001 edition of Timemagazine with its focus on Aids in Africa. I explore the extent to which Jo-Ellen Fair's viewpoint on news as reinforcement of the "relations of ruling" holds true. This essay will focus on how the binary oppositions "us" versus "them" came into being and more particularly on how the magazine's depictions of HIV/Aids and HIV + people intersect with perceptions of race, place and gender. I also argue that Timés framing of this special issue fits the definition of a "doxiconic process" as suggested by Dana Cloud and that the (visual) rhetoric of HIV/Aids has many similarities to what she sees as a culture clash in the rhetoric of the (American) war on terrorism. Key words: Time, representation of HIV/ Aids, race and Aids, gender and Aids.

\section{Introduction}

"Media audiences are especially dependent on the media as information sources and for guidelines about how to feel and how to react" (Stein, 2001).

In recent years, the ways in which the developing world is written about and analyzed have been subject to intense scrutiny, reflecting the influences of broader philosophical and theoretical debates that have swept through western social and political sciences (McEwan, 2001: 93). For example, in her essay on the coverage of "Bride Burning" in the Dallas Observer, the US-based postcolonial scholar Rhadika Parameswaran (1996: 70) argues that Western media discourses covering "Third World" issues tend to homogenize and essentialize "the" Third World and its people. To punctuate her point, Parameswaran recalls Peter Dahlgren and Sumitra Chakrapani's observation that the media's tendency to essentialize the Third World is a strategy that ultimately serves to cast the Third World as "other". Furthermore, "incessant glimpses of disorder and violence serve as a reminder that these societies continue to act out their essential character; they are virtually driven by violence. In direct opposition to this portrayal, 'we', the in- 
dustrialized West, are typified by order and stability, a higher form of civilization." This same tendency towards essentialism and homogenization has been noticed in media discourses on HIV/Aids. Research also points to a preoccupation in the media (and certain research reports) with creating artificial boundaries that separate HIV + people from the rest.

Mary Crewe (1992: 14), director of the Centre for the Study of Aids at the University of Pretoria, South Africa, for example notes that some Western comments on Aids have been deliberately racist; while much media coverage, and some research, have also been racially biased, whether consciously or subconsciously. Like Dahlgren and Chakrapani, Crewe also sees this as a move towards creating a binary opposition of "us" versus "them": "The response to HIV/Aids globally has seen the dominant white power bloc of the 'First World' blame gays and blacks for introducing the disease to a previously 'healthy' society (...). To be able to blame others is psychologically reassuring: the fact that it is their fault divides 'us' from 'them'. We are innocent, at the mercy of fate - they are guilty, and have behaved in such a way as to put us all at risk (Crewe, 1992: 14). Attempting to historicize this reaction, Crewe (1992: 17) writes that

the response to Aids in SA and internationally has been dominated by the political, social and cultural assumptions of white middleclass people. Throughout history, the dominant sector of society has held socially marginalized groups, ethnic minorities and the poor responsible for epidemic diseases. Jews were blamed for the Black Death in Europe, the Irish were blamed for cholera in New York and the Italians were accused of introducing polio into Brooklyn. Foreigners were blamed for syphilis - the French called it the Italian disease, while the Italians called it the Spanish disease.

Drawing heavily on Foucault, Crewe sees the resultant moves towards isolation and quarantine for the inflicted as ways of expressing public fears about outsiders or socially unacceptable groups. This, it is argued, functioned yet again to give concrete form to the desire to create boundaries between the "diseased" and the "clean", which in turn structures public opinion of both disease and those living with disease.

In line with this position, US-based Indian scholar Bardhan (2002: 221) posits that the HIV/Aids pandemic is a phenomenon that is as socially, symbolically and communicatively constructed, as it is a biomedical "reality". The meanings attributed to it are culturally diverse 
and emanate from the lived as well as mediated experiences of those directly and indirectly involved in its discursive and retroviral folds. However, the views, values and perspectives privileged and endorsed at larger societal levels rhetorically and politically shape the future courses of action, policy and signification (Bhardan, 2002: 222). Drawing on journalism scholar Jo-Ellen Fair's use of the term "relations of ruling" I shall argue here that these discourses serve to assign, legitimate and normalize difference and hierarchy within society. Fair (1996: 7) asserts that news stories constitute social relations in their creation, preservation and mediation of a given reality. They carry with them the properties or characteristics of knowledge organized and processed by institutions that are part of the system of ruling. She concludes that texts produced by institutions structure the very ways people think and live. News, as the professional discourse of journalists, provides categories within which "facts" are named and understood, thus they play a key ideological role in constructing HIV/Aids in Africa. In Fair's view, news texts are ideological because the reality it represents is embedded in, articulates and extends ideas and discourses of those who rule rather than those who are ruled.

This observation is shared by Dana Cloud who argues that images work to establish a racialized and nationalist frame for discourses about the war on terrorism and proposes the use of the term "doxiconic" to describe the process by which this happens. A doxicon is "an iconic image that constitutes, in condensed form, the doxa, or set of commonsense theories about social relations in the world, of a social collectivity" (Cloud, 2002: 2). In Cloud's view, doxicons are a powerful part of motivating publics to identify with national aims and to vilify "others" (2002: 34). Cloud argues that, in the rhetoric of "the war on terrorism", these images operate within the racism of the white man's burden and thus serve to warrant racial profiling and war. In the HIV/Aids rhetoric, I shall argue, a similar doxiconic frame is established in which HIV/ Aids is firmly structured as a "Black disease" that came about as a result of "their" cultural and behavioural "ignorance" and thus forces those who are not Black or African to intervene on their behalf.

I shall further explore the extent to which Fair's viewpoint on news as reinforcement of the "relations of ruling" holds true for the February 12, 2001 edition of Time magazine, with its focus on Aids in Africa. I am interested to explore how the binary oppositions "us" versus "them" came into being in this special issue and more particularly to see how Time's depictions of HIV/Aids and HIV+ people, intersect with per- 
ceptions of race, and gender. I shall also argue that Time's framing of this special issue fits the definition of a "doxiconic process" as suggested by Cloud and that the (visual) rhetoric of HIV/Aids has many similarities to what she sees as a clash of cultures in the rhetoric of the war on terrorism.

\section{HIV/Aids and the media: framing the disease}

"Lurid descriptions, first seen perhaps in cancer talk, are even more vividly presented in accounts of Aids. The infection is described in high-tech warfare terminology that is matched only by Ronald Reagan's Star Wars fantasy and its video-game equivalents" (Crewe, 1992).

"First World coverage of Aids in Sub-Saharan Africa has an unfortunate tendency to fall into the category of what can sometimes be called 'Death Voyeurism' (...) the largest theme category for all US news magazines covering Aids in Sub-Saharan Africa was the 'disaster/devastation/hopelessness' theme which is seen to appeal to a large mainstream audience and to fulfil (sic) the dramatic requirements for achieving entertainment value" (Garret, 2000).

In South Africa and elsewhere in Africa, the discourse about HIV/Aids is often embedded within the rhetoric of war and/or competition. For example, in the introduction to an article on Aids in Swaziland, Daly (2000: 20) writes, "the kingdom of Swaziland is at war. The enemy, however, is not another country or people, and the battle is not among rival tribes or social classes. Rather, the struggle is against an internal foe - HIV/Aids." This rhetoric carries over to the visual images about HIV/Aids and people living with Aids (PLA's). In September 1999 for example, an editorial cartoon appeared in two South African newspapers, the Mail \& Guardian and the Sowetan. The cartoon depicts three skeletons representing war, Aids and malaria in what is probably a soccer stadium (the slant on the African Cup of Nations - All Africa) with thousands of fans in the background. It gives a grim picture of Africa's future - one in which only death is certain. It sets the people of Africa straight: in the race against Aids, there are no victors.

Two important ideological inferences emerge from the cited example: Aids affects Black Africa (soccer is perceived as a "black" sporting code in South Africa and elsewhere in Africa) and African Governments are not even in the run - it is a sports commentator who an- 


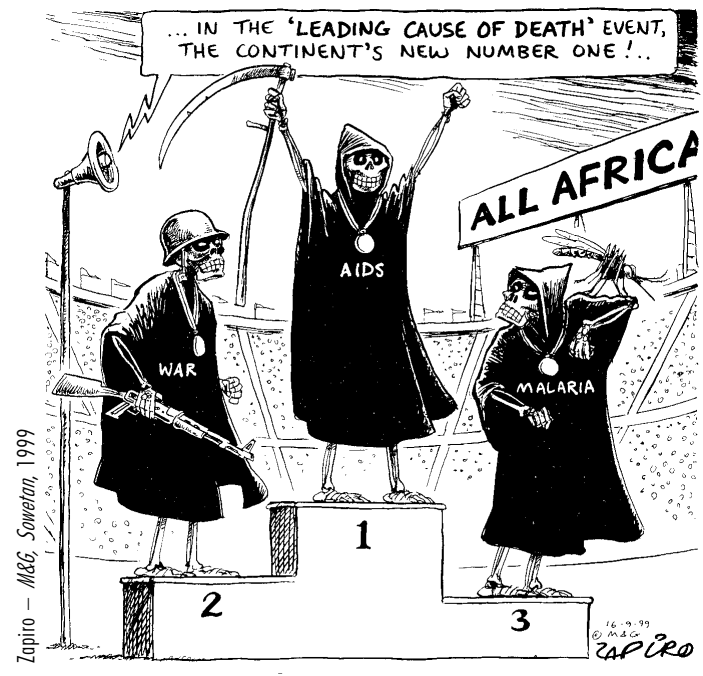

nounces the winner. Furthermore, there is no turning back for Africa none of the competitors represents life - it gives a grim account of a nation about to be wiped out. This was also the message conveyed to the international public in March 2000 in a threenight edition of Nightline, the ABC news magazine programme, entitled "Aids in Africa: The Disappearing Society". The February 12, 2001 special issue of Time magazine covering Aids in Africa reproduced this same message of doom yet again, but with a twist. It told Westerners that "you can do something about it" - even if the African nations themselves could not.

Australian based sociology and cultural studies professor, Deborah Lupton, notes that HIV/Aids has caught the popular imagination like few other diseases before. Since its "discovery" in the early eighties and to this day it remains one of the most reported topics in health broadcasting (Lupton, 1994: 22). Yet how it is reported is not free from bias. Lupton notes that Kitzinger and his colleagues' audience-research into the influence of British news media in shaping beliefs of the general public about Aids, found that in the majority of stories about HIV/ Aids in the news media, HIV-related disease has been presented as a condition affecting social and/or demographic minorities - groups whose exceptional behaviour has put them at special risk. "Many participants specifically recalled the ways in which the early reporting of Aids links it to Africa, Haiti or the Third World (...) journalists both drew upon and helped to reproduce certain cultural assumptions about Aids and Africans in their reports" (Lupton, 1994: 11). In looking at Time it would appear that the same cultural assumptions drive the photo essay that is meant to stir and move readers to action. I believe that the framing of the photo essay exemplifies what Cloud described as a "clash of civilizations".

\section{The visual rhetoric of HIV/Aids in Africa: Time's photo essay}

"More than anything, the photos of 'Aids Victims' struck me (...) every single media image of a person with Aids I could find had that 
person in a passive, submissive position, reclining, huddled over a suitcase, lying in a hospital bed. Their wrists were limp, and they were useless" (Gevisser, 1995).

Although some changes did occur in news coverage of HIV/Aids since Gevisser's observation in 1995, ${ }^{1}$ a lot of news photography (see for example Anon., 2000; Anon., 2001 and Swanepoel, 2001) still appears to be at odds with placing the HIV + person in a position other than "victim". Gevisser describes this as a "peculiar obsession of the media" to continue with "this nonsense of guilt and innocence" which served (at least in South Africa) first the apartheid government's disregard for gay and black people and later the post-apartheid government endorsed silence about the severity of the disease in South Africa (Gevisser, 1995: 7; Stein, 2001: 7). A look at the opening photograph of Time's photo essay $^{2}$ reveals that even though attention is now paid to the severity of the disease, with an almost exclusive focus on black people, the frame of victimhood and despair remains in place. This introductory picture to photographer James Nachtwey's photo essay entitled Crimes against humanity, appears with the following caption: "Even as you read this, Aids is taking lives in Sub-Saharan Africa, swallowing families, communities, hopes (sic). So far 17 million have died. At least 25 million may follow. An intimate look at a modern curse." Presented in this image is a presumably HIV+ woman, in the exact same position of helplessness and despair described by Gevisser in 1995. She has to be taken care of (and the one positive here is that the caregivers are all presumably from the village - thus for the moment placing the stereotype of Black communities ostracizing the HIV+ on the background) and looks like she might die at any moment. The feeling of hopelessness and despair emanating from the body of the woman is reflected also in the choice of black and white-photography as opposed to colour. The use of black and white photography here serves to punctuate and aestheticize despair and eventually death, much as was the case with Spielberg's use of black and white imagery to present footage of war in Saving Private Ryan. Black and white photography also gives the impression of "realistic" or objective documentation, inviting the reader to see the harshness of the reality of peoples' lives without the distraction of colour.

Before one gets to this picture though, how you are supposed to react to it is already set up by the cover of the magazine which invites the reader to look, feel and maybe act. The Time's cover gives the reader 


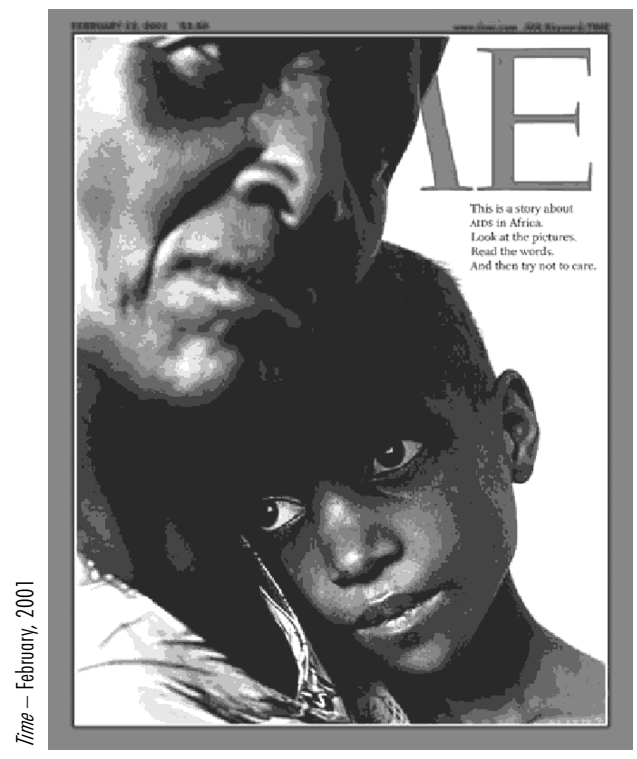

a picture of an older black woman holding a young, thin black child with big eyes. The woman appears more likely to be the child's grandmother than mother and her body takes up most of the space on the cover, almost completely covering the title of the magazine. Both woman and child are not looking at the camera, yet the viewer cannot help but focus on the expressions in their eyes (especially the child's) and their drooping mouths which all seem to suggest a lingering sense of sadness. Captioned, next to this picture, are the words: "This is a story about Aids in Africa. Look at the pictures. Read the words. And then try not to care."

Right here, at the very beginning the combination of picture and words set the reader up with an expectation that s/he will see pictures of HIV + people in need of care. The reader is also led to understand that "care" here is to be interpreted as feeling in the first place, but most likely also action. The last can be inferred both from the almost daring tone of the last sentence - "try not to care", as well as a cursory glance at the Aidsarticles in the table of content. The editors clearly seem to expect that some kind of transformation will take place on the side of the reader and that this transformation would be beneficial ultimately to those being looked at.

The notion of seeing as transformation is reminiscent of James Elkins's position that "seeing is metamorphosis, not mechanism", an interaction between observer and observed that transforms both parties (Elkins, 1996: 2). Elkins discusses the power structures and emotive aspects involved in gazing and describing the object of the gaze. This is both similar and slightly different from how postcolonial scholars view the impact of the gaze: seeing does more than just alter the emotions of those being studied, it also has serious implications for how people are "ranked" in (the global) society. Fair (1996) talks about how the pictures of the famine-ridden bodies of Ethiopian women for example, helped to get foreign aid to Ethiopia. At the same time however, the Ethiopian people are being depicted as helpless victims who cannot take care of themselves. She points out that this is a false depiction, since the very 
women who become transformed by "our" gaze as helpless have done a lot. One could certainly argue that a transformation took place for both observer (realized the precarious position of those less fortunate and are persuaded to aid in some manner) and the observed (from being a "go-getter" to a "helpless victim"), but it seems to me that this transformation process reinforces rather than challenges the existing hegemonic positions in the global society. Time magazine's photo essay falls into the trap of the same transgression. In spite of photographer James Nachtwey's postscript framing of this essay as an attempt towards "journalistic activism," ${ }^{3}$ this activism is not without bias. Instead the transformation that Time calls for in fact operates simultaneously within a framework of recognition and misrecognition that consequently leads to a distortion of the impact of the epidemic in Africa (particularly in the regions covered by Nachtwey). This functions to sustain popular beliefs in these regions and internationally that HIV/ Aids in Africa is black, that black governments aren't doing much to combat the disease. It therefore, once again, becomes the white man's burden.

Moeller (2000: 90) notes that the media reflects the pervasive political climate and follows the lead of "those with power". Thus for example there was an increase in media attention towards Aids coverage in the weeks before the Durban 2000 Aids conference, a "flocking to cover the emergency now that it was government-certified". Bracken (2000:1) however notes that such a turn in coverage is also steered by specific political agendas: "the decision by the White House to categorize Aids in Africa as a threat to national security, the focus on drug prices and pharmaceutical company profits, and the outrage provoked by President Mbeki's skepticism about the relationship between HIV and Aids" is the context within which the proliferation of media attention toward HIV/Aids on the African continent should be read. This to me seems very similar to the rhetoric of war on terrorism. The categorization of Aids in Africa as a threat to national security (presumably in the USA), steers the overriding themes within which Time magazine frames Aids in Africa, thus showing clearly that recognition is not free from ideology.

Charles Taylor (1994: 25) asserts that the demand for recognition in contemporary politics is based on the thesis that our identity is partly shaped by recognition or its absence, often by misrecognition of others. Therefore, it is argued, a person or a group of people can suffer real damage, real distortion, if the people or society around them mirror a confining or contemptible picture of themselves. Nonrecognition or 
misrecognition can inflict harm; it can be a form of oppression, imprisoning someone in a false, distorted and reduced mode of being. I have argued thus far that in the fight against Aids in Africa, widely circulated images tended more towards misrecognition in that they reinforce hierarchies and mirror back to black Africans a distorted and contemptible picture of themselves. As Cloud notes in her study on the war against terrorism, in the HIV/Aids discourse, these images have warranted Western intervention towards the African continent in ways that are difficult to contest on a rational basis. In the discussion that follows, I shall turn my attention more explicitly towards "how" West$\operatorname{ern}^{4}$ (more specifically American) intervention is framed visually as a "deed of salvation" from the culturally attuned to the culturally inept in Time's photo essay.

Although the images that will be discussed here all appeared in the Time issue of February 12, 2001, they are available to audiences at the Time.com archive independent of time and place (see http:// www.time.com/time/2001/Aidsinafrica/photo.html to gain access to the photo essay). In what follows, I looked at the kind of discourses and images presented in the material and the ways in which image and words connected to organize a mediated reality about HIV/Aids, seropositivity and African identities. These images are representative of the most common type of images circulating in the mass media even though it claims a move towards activism. Furthermore, visually at least, activism is structured mainly as coming from the outside, rather than the inside and where there are cases of insider activism, these intersect in interesting ways with perceptions of race and gender.

\section{The HIV+ person as "other": race as marker of disease}

According to Time the photographs in the essay were taken in SubSaharan Africa, which spans a wide variety of countries on the continent. However, a scrutiny of the 26 photographs in the essay reveals that they are all taken in South Africa, Zimbabwe and Botswana - all of which have fairly large white populations in relation to the rest of Africa. Yet, the photo essay explicitly frames the HIV+ person as black. All the photographs of the HIV + consist of black people. There is only one white person represented throughout the essay, a Sister Francis Kay who is photographed giving aid to a black HIV + male. Her HIVstatus remains ambiguous. The photographs are organized in frames of four pictures alternating with frames of single pictures. Sister Francis Kay appears in a group of four. She is giving a foot-massage to a patient 
in a hospice in Zimbabwe. When, in the online version of the photo essay, one scrolls over her picture, the caption identifying the hospice and her name appears. The very next picture is of a patient and an anonymous caregiver in the same hospice, this time however an alternating caption appears. One caption simply states that the patient's lesions are taken care of by a caregiver, but the second caption reveals that all the caregivers in the hospice are HIV + . One is left wondering why this last caption did not alternate in the Sister Francis Kay frame and then one realizes that while the person in the follow-up photo is explicitly identified as a caregiver, Sister Kay is simply introduced by name. Thus she may or may not be a caregiver in the hospice, and therefore may or may not be HIV+.

When, during my sojourn in the USA, I complained about the racialized portrayal of HIV/Aids in the news media covering Africa, the most common response was, "Well, HIV/Aids is the highest amongst the black population - what is your problem?" Certainly it is true that seropositivity is the highest in the black community. The problem however is that portraying the disease as "only black" obscures the fact that HIV/Aids also affects people from all communities, across racial boundaries. A 2002 study conducted by the Human Science Research Council in South Africa for example points out that seropositivity for whites in South Africa is six times the number for Europe and the USA, while both regions have much larger white populations (Shishana \& Simbayi, 2002). Images like these thus serve a double function: first HIV/Aids is framed as a "black" disease. Hawk (1992: 152-153) discusses the ideological positioning of hierarchies being invoked by such portrayals an uncivilized "they" who cannot even take care of themselves, the "that's just the way they are" factor. Secondly, such portrayals, as has been argued by Parameswaran, Hawkes and Lakoff (in her essay on the "fallacy of normalcy") serve to subject those portrayed to an inferior positioning, by normalizing the culture and rituals of the authors (and those like them) as both "normal" and "better". Philomena Essed (in Campbell, 1995: 11) adds to this that when "racism is transmitted in routine practices that seem 'normal', at least for the dominant group, this can only mean that racism is often not recognized, not acknowledged - let alone problematized - by the dominant group."

\section{Gender and HIV/Aids}

Images of women and men are deployed in the Time photo essay in two ways: while both men and women are portrayed as emasculated and 
weakened by disease, some of the pictures evoke a frame of activism on the side of the women, while the only male activist to appear is an unseen corpse in a coffin. Images of emasculated men and helpless women are juxtaposed with images of children - the "orphans" of the epidemic whose plight should ultimately stir the "care" that the article called for earlier. Captions accompanying the children and women for example frequently frame them as abandoned and "on the street" - the implication being that these are the people that need "our" rescuing from disease and violence.

The one instance where activism is clearly marked, fails to redeem the people under scrutiny. I am referring here to slide 6 , which contains the photographs of the young Zulu-women participating in a practice of virginity testing. The captions for both photographs refer to virginity testing as promoting abstinence, but fail to contextualize South Africans' reaction to the practice; it also fails to contextualize the practice within the broader context of sexual abuse in South Africa. Several South African newspaper articles appearing in 2001 noted that because of the increasing awareness of HIV/Aids, indigenous rural communities in South Africa are returning to a practice of virgin testing to ensure that their daughters do not practice sex out of wedlock. This has caused an outcry from feminist and social workers who complain about the dehumanizing of the female body, and the unhygienic circumstances under which these rituals are performed (which could increase the risk of spreading the HIV-virus to others should one of the girls be infected) as well as the increasing risk of rape by believers in the sexwith-a-virgin myth ${ }^{5}$ that some men still believe. The virgin testingritual concludes with a ceremony where the girls are awarded a white star on the forehead to certify their virginal status, as can be seen in the photographs presented here. Thus, this attempt at activism is nullified by its implications for gender-based violence and the risk factors for infection. It could be argued of course that their inclusion is specifically because of these problems: it would irk especially the feministinclined enough to maybe stir them to action. While this transformation takes place for the viewer though, the African communities are subjected to positions of inferiority because of the demonstration of their inability to cope with the disease in "acceptable" (read: Western) ways.

Activism (albeit gendered and skewed) is not the only thing attributed to women in these photographs. Blame is also assigned to them. In the sequence of photographs that form part of slide 6 , a picture of a 
bare-clad female prostitute forms the head of a triangle with the two virgin-testing photographs. In the photograph, the woman is seen posing for a booze-drinking male who is smoking an unidentified substance. The caption makes no reference to the male, rather it reads: "Their trade has dramatically accelerated the spread of Aids in Southern Africa" and then alternating with this sentence, "A prostitute solic-

its clients at a hotel in Harare." The caption undoubtedly functions to scapegoat the females for spreading the disease. No mention is made of the fact that men have to take action too or they would not have become infected, and curiously there is also no mention of the economic conditions that force women to sell their bodies - though this last fact is mentioned briefly in one of the personal stories featured in the article section of this issue of Time. The fact that it is omitted within this frame reinforces stereotypes about the over-sexualized body of the black female. This again functions to place the cause of the spread of the disease firmly within the "nature" of the African. The second caption reinforces this idea: even though it is evident from the picture that the man and woman are already in the hotel room (there is a bed and she is standing against a wall with several pictures), the caption refers to her "soliciting men," (note the plural) with no mention of the fact that she already has a captivated audience in the male present in the photograph. Whereas the first process of othering pitted white against black, this second form pits men against women. In both of these themes, existing relations of ruling are reinforced: whites are still the dominant power globally and, in Africa at least, women are still very much subjected to the will of men.

\section{Conclusion}

I have pointed out here that Time's photo essay sets up binary oppositions that reinforce the existing relations of ruling in a global society. The images presented here are structured in such a way as to conform to so-called common sense theories about social relations in the world. As such, these images present the problem of HIV/Aids in Africa as black, while at the same time confirming stereotypes about the hopelessness of black governance on the African continent.

In one sense, this conclusion is a cliché: There is a disproportionate focus on tragedy in the media coverage of Aids in Africa; death and hopelessness are visually structured as a "black" problem, to the exclusion of all other racial communities on the continent. Due to "their" hopelessness it is necessary for the outside world to intervene, lest their 
problem also become "ours" (as evident in the move by the White House to declare Aids in Africa a threat to [the USA's] national security). Why then should we continue to research and write about this?

Processes of othering serve to feed sensationalism and tend to obscure critical issues that need to be highlighted. I have mentioned earlier that the problem with these portrayals is that they obscure the fact that Aids in Africa is as much a general problem as it is "a black problem", at the same time it also serves to pit black against white. By framing the disease as black and resultant of "the nature of the black" the media not only serve to homogenize the group into oneness (totally ignoring for example ethnic differences between black people), it perpetuates a universal discourse in which the African is seen as "deviant and so different" that any chance to redeem "them" is doomed to failure. By completely ignoring success stories it obscures the fact that much has been done in African nations to combat the disease (see for example the success reported in Uganda) and thus perpetuates the stereotype that success is only possible if the framework for knowledge is Western. The problem with this is that funding for indigenous solutions (which has been used with relative success in countries such as Uganda and Senegal) gets blocked making the countries and people of Africa totally dependent on the powers of the West. It furthermore blocks aid (for example development communication projects to raise awareness) to African populations who are not seen as part of the problem (such as minority communities in South Africa) which in turn leads to a continued increase of infection rates in these communities as they do not see themselves at risk.

\section{Notes}

1. In terms of news stories for example, it has been noted that since 1999 some journalists succeeded in providing less biased coverage by integrating the perspectives of people living with HIV/Aids, the larger cultural, economic and political context which shapes the epidemic and the science of HIV (Stein, 2001: 7).

2. Due to copyright restrictions the photographs discussed here could not be reproduced. It can be viewed on Time.com at http://www.time.com/time/2001/Aidsinafrica/photo.html.

3. "Although the Aids epidemic is a devastating postscript to a story that embodied the best that humanity has to offer, there is no alternative but to defeat it. That can be accomplished only through awareness and education, both within the countries affected and in the rest of the world, which must lend support and assistance. My goal, as a photojournalist, as it has been from the beginning, is to help create that awareness" (Nachtwey, 2001).

4. The use of the concept "Western/Westerner" is of course subject to the same arguments as those stated earlier against the use of the term "African". I use it here as the obverse of "African" as is generally the practice in development communication literature. It should however be noted that the use of "Western/Westerner" here refers mainly to America/Americans as the magazine photo essay that I am discussing originally circulated in the USA. Of course, with the photo essay circulating on the Internet, one could argue that the addressed reader now spans a much wider 
range, but for the sake of clarity and definition, I would argue that it is the intended/ original reader that should be highlighted in this discussion.

5. This is a belief that sex with a virgin can either cure an HIV positive man from Aids or prevent a man from being infected by the HIV virus. The Colleges of Medicine of South Africa (CMSA) report that "[I]nfant rape appears to be related to the myth that intercourse with a young virgin can allow the perpetrator to rid himself of HIV/Aids. This is seen as an act of purification" (Anon., 2002: 1).

\section{Bibliography}

Anon. 2000. Image Gallery: Pictures from the front line. CNN.com http://www.cnn.com/2000/WORLD/ europe/06/28/uk.disasters/index.html. Accessed: 28 July 2003.

Anon. 2001. Africa devastated by Aids. BBC. http://news.bbc.co.uk/2/hi/africa/1679619.stm. Accessed: 28 July 2003.

Anon. 2002. Doctors condemn child rape. News24.com. http://www.news24.com/News24/South_Africa/ 0,6119,2-7_1140675,00.html. Accessed: 28 July 2003.

Bardhan, N.R. 2002. Accounts from the field: A Public Relations Perspective on Global Aids/HIV. Journal of Health Communication, 7: 221-244.

Bracken, J. 2000. [O] The Band keeps on playing: The MediaDisservice on Aids in Africa - The Press didn't learn from its mistakes. www.tompaine.com/nes/. Accessed: 28 July 2003.

Campbell, C.P. 1995. Race, Myth and the News. London: Sage.

Cloud, D. 2003. The "Clash of Civilizations" in the Doxiconic Visual Rhetoric of the War on Terrorism. Unpublished manuscript.

Crewe, M. 1992. Aids in South Africa. The Myth and the Reality. London: Penguin Books.

Daly, J.L. 2001. Aids in Swaziland: The Battle from within. African Studies Review, 44 (1): 21-35.

Elkins, J. 1996. The Object Stares Back. New York: Simon \& Schuster.

Fair, J.O. 1996. The Body Politic, the Bodies of Women, and the Politics of Famine in U.S. Television Coverage of Famine in the Horn of Africa. Journalism and Mass Communication Monographs, 158 (August): 1-41.

Garrett, L. 2000. You just signed his death warrant: Aids Politics and the Journalists role. In Stein, J. 2001. HIV/Aids and the Media. A Literature Review. Johannesburg: Cadre.

Gevisser, M. 1995. Aids and the Media. Aids Bulletin, 4 (1): 6-9.

Hawk, B.G. (ed.). 1996. Africa's Media Image. New York: Praeger.

Lakoff, Robin. 1990. Talking Power: The Politics of Language in Our Lives. New York: Basic Books.

Lupton, D. 1994. Moral Threats and Dangerous Desires. Aids in the News Media. London: Taylor and Francis.

McEwan, C. 2001. Postcolonialism, feminism and development: intersections and dilemmas. Progress in Development Studies. 1(2): 93-111

Moeller, Susan D. 2000. Coverage of Aids in Africa: The Media are silent no longer. Nieman Reports, 54(3): 89-94.

Nachtwey, J. 2001. [O] Photo Essay: Crimes Against Humanity. Time, February 12. http://www.time.com/ time/2001/Aidsinafrica/photo_flash.html. Accessed: 28 July 2003.

Parameswaran, R. 1996. Coverage of "Bride Burning" in the Dallas Observer: A Cultural Analysis of the Other. Frontiers Editorial Collective,16 (2/3): 69-100.

Shishana,O. \& Simbayi, L. 2002. [O] Nelson Mandela/HSRC Study of HIV/Aids. South African National HIV Prevalence, Behavioural Risks and Mass Media. Household survey 2002. http://www.cadre.org.za/pdf/ HIV\%20Report.pdf. Accessed: 28 July 2003.

Stein, J. 2001. HIV/Aids and the Media. A Literature Review. Johannesburg: Cadre.

Swanepoel, T. 2001. Dames en here, hoe voel dit om te kibbel terwyl kinders sterf? Beeld, November, 2.

Taylor, C. 1994. The Politics of Recognition. In Gutman, A. (ed.). Multiculturalism: Examining the Politics of Recognition. Princeton: Princeton University Press. 